\title{
Extra vertebrae in Ingres' La Grande Odalisque
}

\author{
Jean-Yves Maigne MD1 $\quad$ Gilles Chatellier MD² Hélène Norlöff3
}

J R Soc Med 2004;97:342-344

\section{SUMMARY}

La Grande Odalisque, a painting by Jean-Auguste Ingres (1780-1867), was throughout the 19th century notorious for its anatomical inaccuracy; in particular, the woman was said to have three lumbar vertebrae too many. This view was accepted by all art critics, but never tested and proven. We measured the length of the back and of the pelvis in human models, expressed the mean values in terms of head height, and transferred them to the painting. The deformation was found to be greater than originally assumed (five, rather than three, extra lumbar vertebrae), and to involve both the back and the pelvis. Ingres' paintings skilfully combine realism and symbolism. We suggest that the deformation may have been introduced for psychological reasons. By placing the harem woman's head further away from her pelvis the artist may have been marking the gulf between her thoughts (expressed by her aloof, resigned look) and her social role (symbolized by her deliberately lengthened pelvis).

\section{INTRODUCTION}

La Grande Odalisque (1814) by Jean-Auguste Ingres (1780 1867), the figure of a harem woman, was criticized from the start for its faulty anatomy (Figure 1). ${ }^{1}$ Most memorably, the art critic de Kératry told Ingres' student Amaury-Duval: 'His Odalisque has three [lumbar] vertebrae too many.' 2 Since then, this remark has been regarded as proven fact. ${ }^{3}$ Art critics concur that Ingres had lengthened the figure's back to lend it more bulk. We felt that the matter was more complex, and that a better understanding of the deformation might improve our appreciation of the painting. This led us to devise a study of La Grande Odalisque to establish the number of her vertebrae. We measured the back and the pelvis of human models, related the data to head height, and transferred the measurements to the painting.

\section{METHODS}

Measurements were performed in normal young women and in the painting. The figure in the painting displays several anatomical landmarks - the protruding spinous process of the seventh cervical vertebra (C7), the dimples over the posterior superior iliac spines, and the lower margin of the buttocks. These landmarks were used to define two regions - the back and the pelvis — which could be measured and related to head height.

'Department of Physical Medicine, Hôtel-Dieu Hospital, Place du Parvis NotreDame, 75181 Paris Cedex 04; ${ }^{2}$ Clinical Epidemiology Unit and Medical Informatics Department, Hôpital Européen Georges Pompidou, 20 rue Leblanc, 75908 Paris Cedex 15; ${ }^{3} 7$ avenue Franklin Roosevelt, 75008, Paris, France

\section{Measurements in young women}

The normal subjects (the models) were nine tall young women (height 178 SD $4 \mathrm{~cm}$; body mass index [BMI] 20.2 SD $\left.2.4 \mathrm{~kg} / \mathrm{m}^{2}\right)$. Obesity $\left(\mathrm{BMI}>27 \mathrm{~kg} / \mathrm{m}^{2}\right.$ ) and scoliosis were exclusion criteria. All gave informed consent. Head height was measured from the vertex to the chin. The models were placed in a position that matched that of the Odalisque as much as possible (Figure 2). Back height was measured in terms of the following subunits: from the spinous process of $\mathrm{C} 7$ to the interspinous ligament between the twelfth thoracic vertebra and the first lumbar vertebra (upper back); and from that ligament to a line joining the skin dimples over the posterior superior iliac spines (lower back); the pelvis was measured from that line to the lower margin of the buttocks. These measurements were first performed in a pilot series of five individuals, to determine feasibility, and then made in the nine models participating in the study. Each measurement was performed twice by the same investigator. The mean value of the two measurements was used for the study, and expressed in terms of head height.

\section{Measurements in the painting}

The same distances between landmarks were measured in a $137 \mathrm{~cm} \times 86 \mathrm{~cm}$ reproduction of Ingres' painting, each measurement being performed three times by the same investigator, with the mean of the three being used as the definitive value. The Odalisque's head height was used for the assessment of the height of her back and pelvis without the deformation, and to assess the actual deformation. Since the crown of the figure's head could not be determined with certainty, the classical canons of proportions ${ }^{4}$ were applied. 


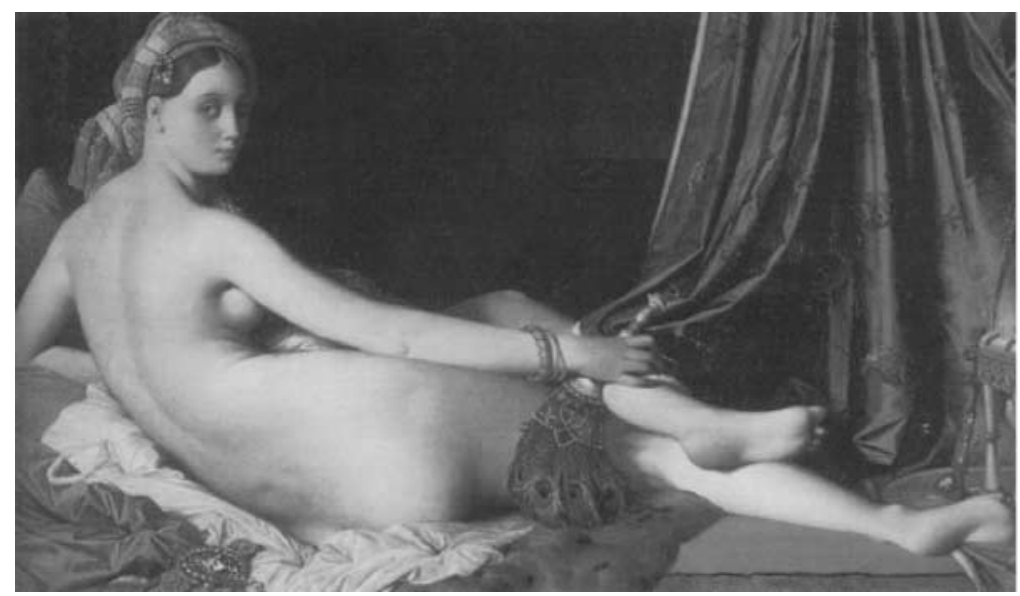

Figure 1 La Grande Odalisque (JA Ingres, 1814), now in the Musée du Louvre, Paris

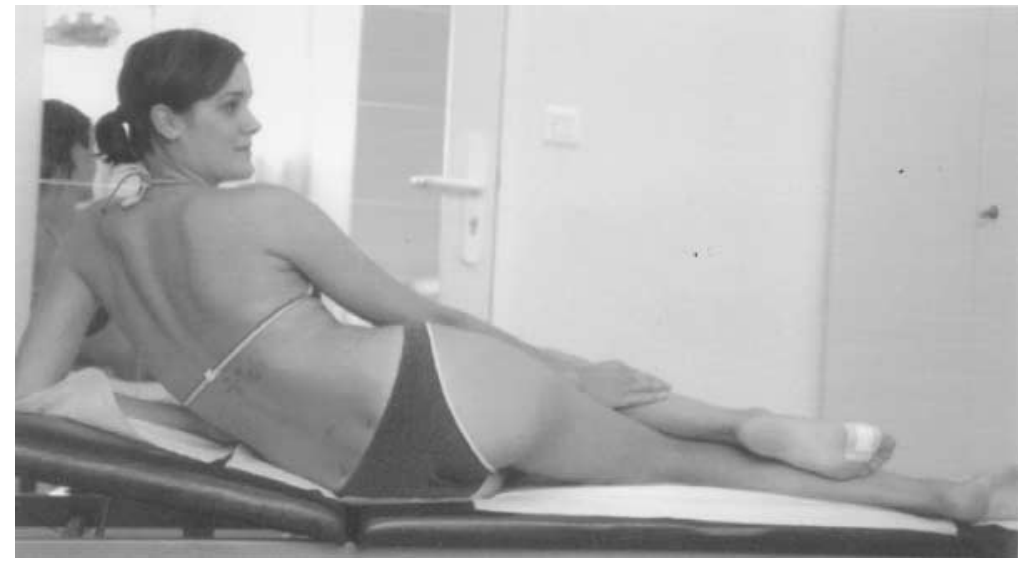

Figure 2 Model placed in the position of the Odalisque for measurements

According to these rules, chin-to-crown head height equals twice the distance between the lower border of the chin and the inner corner of the eye. These structures were readily discernible in the painting.

To ensure a fair assessment, the effect of perspective had to be taken into account. In the painting, the Odalisque's head is in the middle ground, and hence appears smaller. Since the head provided the unit of measurement, it had to be brought into the same plane as the pelvis. To this end, a magnification coefficient correcting the effect of perspective had to be calculated. This was done by producing photographs of the models, in the pose of the Odalisque, using a focal length of $50 \mathrm{~mm}$. Two rods of identical length were held at the level of the head and of the pelvis, respectively. A comparison of their length in the background and in the foreground of the photographs allowed the requisite coefficient to be calculated. It was found to be $9.4 \%$. Since the height of the human pelvis is $x$ times the head height, the Odalisque's pelvis, without any elongation, should have been $x$ times her perspective-corrected head height. For the lower back, a coefficient of $4.7 \%$ (i.e. half that used for the head) was established and applied. The deformations observed in the painting were measured and compared with the measurements obtained in the models.

\section{Statistical analysis}

Paired $t$ tests were used for comparing paired data. Parametric methods were used for the calculation of confidence intervals (CIs). A $P$ value of $<0.05$ was taken as statistically significant.

\section{RESULTS}

For the measurement of head, back and pelvis, the mean difference between the two successive measurements was $0.20 \mathrm{~cm}(95 \% \mathrm{CI}-0.50$ to $+0.11 ; P=0.18), 2.13 \mathrm{~cm}(95 \%$ $\mathrm{CI}-2.90$ to $+7.17 ; P=0.36)$, and $0.88 \mathrm{~cm}(95 \% \mathrm{CI}$ -0.55 to $+2.30 ; P=0.19$ ), respectively. When related to the mean value of the measurements, these measurement errors correspond to a mean error of $1.0 \%, 4.0 \%$ and $4.3 \%$ 
Table 1 Mean length of head, back, and pelvis, in the models $(n=9)$

\begin{tabular}{lll}
\hline Body part & $\begin{array}{l}\text { Height in } \\
\text { cm (SD) }\end{array}$ & $\begin{array}{l}\text { Height (SD), } \\
\text { related to head } \\
\text { height }\end{array}$ \\
\hline Head & $21.8(0.9)$ & 1 \\
Upper back (C7 to T12-L1) & $34.1(1.5)$ & $1.56(0.09)$ \\
$\begin{array}{l}\text { Lower back (T12-L1 to } \\
\text { dimples) }\end{array}$ & $19.3(1.3)$ & $0.89(0.07)$ \\
Back (C7 to dimples) & $53.4(2.1)$ & $2.46(0.14)$ \\
Pelvis & $20.6(1.4)$ & $0.95(0.07)$ \\
\hline
\end{tabular}

$\mathrm{C} 7=$ seventh cervical vertebra. $\mathrm{T} 12=$ twelfth thoracic vertebra. $\mathrm{L} 1=$ first lumbar vertebra

for the head, back and pelvis, respectively. The different heights were first expressed in centimetres and then in terms of head height (Table 1).

When the mean values established in the models were transferred, with correction for perspective, to the painting, the Odalisque's back was found to be $8.20 \mathrm{SD}$ $0.36 \mathrm{~cm}$ longer than in the models, while the excess length of the pelvis was $6.77 \mathrm{SD} 0.25 \mathrm{~cm}$. By calculating the $95 \%$ confidence interval using the $t$ value corresponding to two degrees of freedom, the 'true' increase in back length was between $6.65 \mathrm{~cm}$ and $9.75 \mathrm{~cm}$, while the increase in pelvic length was between $5.68 \mathrm{~cm}$ and $7.85 \mathrm{~cm}$. Thus, from the sum of the mean values, total (back+pelvis) lengthening was $14.97 \mathrm{~cm}$, and $12.33 \mathrm{~cm}$ and $17.60 \mathrm{~cm}$, respectively, taking the lower limit or the upper limit of the $95 \%$ confidence interval of these two values.

Given an average height of the female lumbar spine of $15.5 \mathrm{~cm}$ (extrapolated from a standard textbook of anatomy ${ }^{5}$ ), the Odalisque's back is longer than normal by the height of almost five, rather than just three, lumbar vertebrae; also, contrary to received wisdom, the excess affects the lower back and the pelvis, rather than being confined to the lumbar region.

\section{DISCUSSION}

The deformation of the figure in Ingres' painting is associated with a sideways curve of the trunk and a rotation of the pelvis which proved impossible to reproduce in the models. The visual effect of the excess length is to place the head further away from the pelvis. This impression is enhanced by the fact that the left arm of the Odalisque is shorter than the right.

An odalisque was a woman kept in a sultan's harem. Ingres was well known for the way in which he reflected his subject's social condition through the medium of his paintings. Art critics have repeatedly drawn attention to the contrast between the Odalisque's posture and her facial expression. The gorgeous body is there for the sultan's pleasure. The added pelvic length emphasizes the woman's sensuous beauty. The face, however, has been described as betraying no feeling, ${ }^{6}$ as being sad and indifferent (Théophile Gautier), or aloof and inscrutable, reflecting a complex psychological make-up. ${ }^{7}$ By adding length to the Odalisque's back, the painter may well have been trying to show, in physical terms, the gulf between the woman's condition and her innermost thoughts and feelings.

\section{REFERENCES}

1 Ternois D. Ingres Exhibition at the Petit Palais, Paris. Catalogue 1967; 102:70

2 Amaury-Duval EE. L'atelier d'Ingres, 1st edn. Paris: Champetier, 1878:370 [edition containing preface and notes by D Ternois, Paris: Arthéna, 1993:370]

3 Zimbler MS. Ingres' Odalisque: idealized beauty. Arch Facial Plast Surg 2000;2:C3

4 Richer P. Canon des Proportions du Corps Humain. Paris: Delagrave, 1917:28

5 Williams PL, Warwick R, Dyson M, et al., eds. Gray's Anatomy, 37th edn. Edinburgh: Churchill Livingstone, 1989:329

6 Kératry AH. Annuaire de l'école Française, ou Lettres sur le Salon de 1819. Paris: $1820: 145$

7 Bajou V. Monsieur Ingres. Paris: Adam Biro, 1999:136-41 